\title{
KOMPETENSI PEDAGOGIK GURU PENDIDIKAN AGAMA ISLAM TERHADAP MOTIVASI BELAJAR SISWA SMP
}

\author{
Ujang Dedih \\ Ai Irma Nurajijah \\ Jurusan Pendidikan Agama Islam, \\ UIN Sunan Gunung Djati Bandung; \\ ujangdedih@uinsgd.ac.id
}

\begin{abstract}
Abstrak
The purpose of this paper is to find out the reality of student responses to teachers' pedagogical competencies; to find out the reality of student motivation to take PAI lessons, and to find out the reality of the relationship between student responses to the competence of PAI teachers and their learning motivation in taking PAI lessons. used in this research method is the correlation method. While the data collection techniques used observations and questionnaires that were distributed to 34 students of class VIII SMP 17 Bandung City as respondents. Quantitative data obtained and analyzed using statistical analysis. From the results of the study, it was found that: the reality of student responses to teachers' pedagogical competencies is included in high qualifications, this is evident from the results of the average score of the 15 questionnaire questions submitted at 4.21; the reality of students' learning motivation following PAI subjects is included in high qualifications, this is evident from the results of the average score of 15 items in the questionnaire that were submitted at 4.05.
\end{abstract}

Keyword: pedagogic competence, learning motivation 


\section{A. Pendahuluan}

Belajar mengajar merupakan suatu proses yang mengandung serangkaian perbuatan guru dan siswa atas dasar hubungan timbal balik yang berlangsung dalam situasi edukatif untuk mencapai tujuan tertentu. Interaksi atau hubungan timbal balik antara guru dan siswa itu merupakan syarat utama bagi berlangsungnya proses belajar mengajar. Hanya saja, keterpaduan proses belajar siswa dengan proses mengajar guru tidak dapat tumbuh begitu saja tanpa adanya peraturan dan perencanaan yang seksama (Nana Sudjana, 2004:29). Untuk itu harus ada yang mengatur dan merencanakan pelaksanaan proses pembelajaran disekolah, salah satunya adalah guru.

Guru merupakan faktor yang sangat penting dalam dunia pendidikan. Kebutuhan dan tuntutan masyarakat terhadap guru sangat terasa urgensinya pada pendidikan formal. Sebagai tenaga profesional, tentu saja ada konsekuensi atau standar kelayakan yang harus ditempuh oleh seorang guru (Pasal 8 UU No. 14 Tahnun 2005). Salah satunya, seorang guru wajib memiliki kompetensi. Seorang guru yang berkompeten akan mampu mengelola kelasnya sehingga hasil belajar siswa berada pada tingkat optimal (Usman, 2011:7). Maka dari itu, untuk menunjang semua pencapaian tersebut guru harus memiliki setidak-tidaknya empat kompetensi yaitu kompetensi paedagogik, kompetensi kepribadian, kompetensi profesional, dan kompetensi sosial (Peraturan Pemerintah Republik Indonesia Nomor 19 tahun 2005).

Berdasarkan studi pendahuluan yang dilakukan di kelas VIII SMP Negeri 17 Kota Bandung, bahwasanya guru PAI memiliki kemampuan mengajar yang cukup baik dan telah memenuhi syarat ketercapaian kompetensi paedagogik yang wajib dimiliki oleh seorang guru. Hal tersebut dapat dilihat dari kemampuan guru dalam pemilihan metode dan media pembelajaran yang sesuai dengan kebutuhan peserta didik, kemampuan dalam menyusun RPP yang sesuai dengan materi ajar, dan kepiawaian guru dalam menjelaskan materi kepada peserta didik. Untuk dapat meningkatkan kualitas pendidikan Nasional, dimulai dari kesiapan guru mempersiapkan, melaksanakan dan mengevaluasi pelaksanaan pembelajaran yang dalam hal ini tidak terlepas dari proses pembelajaran di sekolah, khususnya dari peranan guru yang secara umum disebut pendidik. Terpenuhinya buku-buku, sarana-prasarana belajar dan sumber 
belajar yang memadai, tanpa ada peran nyata dari para guru menjadi mustahil pelaksanaan pembelajaran terlaksana dengan baik. Sehingga peran guru sangat sentral yang mampu membawa dampak terhadap hasil belajar siswa.

Menurut Undang-undang guru profesional juga diartikan suatu pekerjaan atau kegiatan yang dilakukan oleh seseorang dan menjadi sumber penghasilan kehidupan yang memerlukan keahlian, kemahiran, atau kecakapan yang memenuhi standar mutu atau norma tertentu serta memerlukan pendidikan profesi yang diterapkan dan terwujud dalam proses belajar mengajar di sekolah. Namun pada kenyataannya masih banyak siswa yang tidak termotivasi. Hal ini bisa dilihat dari sebagian siswa yang tidak memperhatikan pembelajaran ketika berlangsung, misalnya ada yang keluar masuk kelas saat pembelajaran dengan alasan ke kamar kecil, berbincang-bincang ketika sedang belajar atau ketika guru sedang menerangkan, ketika diberikan tugas masih ada yang tidak mengerjakan, dan konsentrasi peserta didik tidak bertahan lama ketika mengikuti pelajaran Pendidikan Agama Islam. Menurut O. Whittaker motivasi adalah berbagai kondisi atau keadaan yang bisa mendorong atau mengaktifkan semangat untuk bertingkah laku kepada makhluk hidup agar tujuan yang diinginkannya bisa tercapai (Evelin \& Hartini, 2010). Motivasi dapat juga dikatakan serangkaian usaha untuk menyediakan kondisi-kondisi tertentu sehingga seseorang mau dan ingin melakukan sesuatu. Jadi motivasi itu dapat dirangsang oleh faktor dari luar tetapi motivasi itu tumbuh dari dalam diri siswa.

Menurut Peraturan Menteri Pendidikan Nasional Republik Indonesia No. 16 Tahun 2007 tentang Standar Kualifikasi Akademik dan Kompetensi Guru, adapun macam-macam kompetensi yang harus dimiliki oleh seorang guru antara lain : kompetensi paedagogik, kepribadian, profesional dan sosial yang diperoleh melalui pendidikan profesi. Keempat kompetensi itu sangat penting untuk dikuasai oleh guru pada umumnya. Standar kompetensi guru dikembangkan secara utuh dari empat kompetensi utama, yaitu kompetensi padagogik, kepribadian, sosial, dan profesional (Wahyudi, $2012: 25$ ).

Guru memiliki tugas yang utama ialah mengajar dan mendidik murid di kelas dan di luar kelas. Guru selalu berhadapan dengan murid 
yang memerlukan pengetahuan, keterampilan dan sikap utama untuk menghadapi hidupnya di masa depan. Berdasarkan tugas guru di atas maka guru harus menguasai kompetensi paedagogik yang mana kompetensi paedagogik adalah kompetensi guru dalam mengajar, membimbing dan mendidik peserta didik (Musfah, 2011 : 30). Adapun indikator dari kompetensi paedagogik menurut Mulyasa (2009 : 75) adalah sebagai berikut : 1) Kemampuan dalam memahami peserta didik, 2) Kemampuan dalam membuat perancangan pembelajaran, 3) Kemampuan melaksanakan pembelajaran yang mendidik dan dialogis, 4) Kemampuan dalam mengevaluasi hasil belajar, 5) Kemampuan dalam mengembangkan peserta didik untuk mengaktualisasikan potensi yang dimilikinya. Pendidikan Agama Islam diartikan sebagai pendidikan yang memberikan pengetahuan dan membentuk sikap, kepribadian, dan keterampilan peserta didik dalam mengamalkan ajaran agama Islam, yang dilaksanakan sekurang-kurangnya melalui mata pelajaran pada semua jenjang pendidikan. Guru memiliki tugas utama dalam hal pendidikan, sehingga penguasaan kompetensi pedagogik merupakan kompetensi yang harus dikuasai guru. Sebab jika dilihat dari indikator kompetensi paedagogik itu sendiri, kompetensi itu sangat penting demi kelancaran pembelajaran, selain itu ada beberapa hal yang harus diperhatikan agar seorang guru bisa lebih baik mengelola kelasnya sehingga memotivasi siswa agar lebih giat belajar

Dalam pembelajaran tidak sedikit siswa yang tidak termotivasi untuk mau belajar. Hal ini bisa dilihat dari sebagian siswa yang tidak memperhatikan pembelajaran ketika berlangsung, misalnya ada yang keluar masuk kelas saat pembelajaran dengan alasan ke kamar kecil, berbincang-bincang ketika sedang belajar atau ketika guru sedang menerangkan, ketika diberikan tugas masih ada yang tidak mengerjakan, dan konsentrasi peserta didik tidak bertahan lama ketika mengikuti pelajaran Pendidikan Agama Islam. Kondisi tersebut menunjukkan bahwa tidak semua siswa di sekolah tersebut termotivasi untuk mengikuti proses belajar mengajar bidang studi PAI, seolah-olah tingkat penguasaan kompetensi paedagogik guru itu tidak memberikan pengaruh sama sekali terhadap motivasi siswa. Secara global faktor-faktor yang dapat mempengaruhi belajar siswa yaitu intelegensi siswa, sikap siswa, bakat siswa, minat siswa, motivasi siswa, lingkungan sosial, dan lingkungan 
nonsosial. Belajar akan lebih maksimal jika seluruh faktor itu bekerja dengan baik. Tetapi jika satu diantara seluruhnya dimiliki oleh siswa itupun akan membantu proses belajar siswa. Salah satunya adalah motivasi. (Syah, Muhibbin:132). Untuk mengantisipasi rendahnnya motivasi belajar siswa akan dilakukan penelitian yang terkait dengan kemampuan pedagogik guru dalam memotivasi belajar siswa.

\section{B. Metodologi Penelitian}

Pada garis besarnya penelitian yang akan dilakukan peneliti adalah dengan menggunakan metode korelasional atau metode korelasi. Metode korelasi adalah bagian dari metode deskriptif. Metode deskriptif adalah metode yang mempelajari hubungan antara dua variabel atau lebih. Bisa juga menghitung sejauhmana pengaruh variasi dalam satu variabel dengan variasi dalam variabel lain. Derajat hubungan pada tiap variabel akan dinyatakan dalam satu indeks yang bernama koefisien korelasi. Menurut Sudjana dan Ibrahim, metode korelasi akan menguji suatu hipotesisi mengenai hubungan tiap variabel atau dapat menyatakan ukuran hubungan pada kedua variabel tersebut. Oleh karena itu, Metode korelasi dirasa sangat sesuai dengan judul peneliti yaitu untuk memecahkan masalah praktis didalam pendidikan yang berhubungan antara satu variable (variable $\mathrm{X}$ ) dengan variable yang lain (variable Y). Jenis data yang digunakan oleh peneliti adalah data kuantitatif. Data kuantitatif adalah data-data yang berhubungan dengan angka. Baik angka tersebut didapat dari hasil pengukuran langsung atau data hasil olahan dari data jenis kualitatif. Misalnya seperti data hasil wawancara dan observasi. Karena data kuantitatif adalah hasil pengukuran prosentase, rata-rata atau perhitungan yang lainnya.

\section{Hasil dan Pembahasan}

\section{Tanggapan Siswa Terhadap Kompetensi Paedagogik Guru PAI}

Analisis korelasional data menunjukkan bahwa terdapat hubungan yang tinggi antara tanggapan siswa terhadap kompetensi paedagogik guru PAI dengan motivasi belajar siswa mengikuti mata pelajaran PAI di SMPN 17 Kota Bandung. Hal ini dibuktikan dengan hasil perhitungan uji hipotesis yang telah dilakukan menggunakan rumus korelasi product moment yang menunjukkan milai lebih besar dari pada signifikansi $(5 \%)=$ 0,05 dan jumlah responden $(n)=34$ siswa. Setelah diinterpretasi, realitas tanggapan siswa terhadap kompetensi paedagogik guru PAI sebesar 4,21\% 
hal ini berada pada interval 3,50-4,50 yaitu tinggi. Selain itu, perhitungan tingkatan hubungan antara variabel tanggapan siswa terhadap kompetensi paedagogik guru PAI dengan variabel motivasi belajar PAI juga cukup kuat.

\section{Motivasi belajar PAI di SMPN 8 Bandung}

Dari hasil perhitungan statistik, motivasi belajar siswa pada mata pelajaran PAI berjumlah 4,05. Angka 4,05 berada pada interval 3,504,50 yang berarti tinggi. Banyak faktor penyebab timbulnya motivasi belajar. Dalam hal ini peneliti menghubungkan dengan penguasaan kompetensi paedagogik guru agama. Karena menurut Evelin \& Hartini dalam bukunya yang berjudul Teori belajar dan pembelajaran (Evelin \& Hartini, 2010) Guru yang selalu menyemangati ketakutan siswa, memuji keberanian siswa, dan memberi kesempatan terhadap siswa yang pemalu dan penakut itu akan meningkatkan motivasi siswa dalam belajar.

Kemampuan melaksanakan pembelajaran yang mendidik dan dialogis, yaitu kemampuan berkomunikasi dengan siswa dan memberikan kesempatan yang sama kepada semua siswanya. Ketika seorang siswa yang pemalu atau penakut diberikan kesmpatan untuk bertanya terkait apa yang belum dipahaminya itu akan sangat berdampak positif terhadap motivasi belajar siswa tersebut, namun sebaliknya jika seorang guru tidak memberikan kesempatan yang sama kepada seluruh siswanya akan berdampak negatif, yaitu menurunnya motivasi belajar mereka ketika pembelajran, dikarenakan sebagian peserta didiknya itu kurang memahami apa yang disampaikan gurunya di kelas. Oleh karena itu Kompetensi Paedagogik Guru di SMPN 17 Bandung harus dipertahankan dan di tingkatkan kembali karena Kompetensi Paedagogik Guru berpengaruh besar terhadap motivasi belajar siswa pada mata pelajaran PAI. Sehingga jika Kompetensi Paedagogik Guru baik maka motivasi belajar siswa pun akan menjadi tinggi

\section{Simpulan}

Berdasarkan data yang diperoleh dari hasil analisis tanggapan siswa terhadap kompetensi paedagogik guru PAI hubungannya dengan motivasi belajar siswa mengikuti mata pelajaran PAI, dapat diambil kesimpulan sebagai berikut:Realitas tanggapan siswa terhadap kompetensi paedagogik guru PAI berkategori tinggi. Hal ini diperoleh dari nilai rata- 
rata jawaban 34 siswa terhadap 15 item angket yang diajukan dan mencapai nilai 4,21. Angka 4,21 termasuk pada kategori tinggi karena berada pada interval 3,50-4,50. Hal ini berarti siswa-siswa SMPN 17 Kota Bandung memberi tanggapan yang sangat positif terhadap kompetensi paedagogik guru PAI; Realitas motivasi belajar siswa mengikuti mata pelajaran PAI di SMPN 17 Kota Bandung berkategori tinggi. Hal ini diperoleh dari nilai rata-rata jawaban 34 siswa terhadap 15 item angket yang diajukan mencapai nilai 4,05. Angka 4,05 termasuk pada kategori tinggi karena berada pada interval 3,50-4,50. Hal ini berarti siswa-siswa di SMPN 17 Kota Bandung memiliki motivasi belajar yang tinggi saat mempelajari pelajaran PAI.

\section{REFERENSI}

Dimyati dan Mudjiono. (2013). Belajar dan Pembelajran. Jakarta: PT

Djamarah. (2011). Psikologi Belajar. Jakarta: Rineka Cipta.

Evelin, S., \& Hartini, N. (2010). Teori belajar dan pembelajaran. Bogor: Ghalia Indonesia.

Muhaimin. (2001). paradigma Pendidikan Islam. Bandung: PT. Remaja Rosdakarya.

Mulyasa. (2009). Standar Kompetensi dan Sertifikasi Guru. Bandung: PT. Remaja Rosdakarya.

Musfah, Jejen. 2011. Peningkatan Kompetensi Guru : Melalui Pelatihan dan Sumber Belajar Teori dan Praktik. Jakarta : Prenada Media Group.

Sahrani, A. S. (2008). Peranan Pendidikan Agama Islam Dalam Mencegah Kenakalan Remaja. Jakarta: PT. Raja Grafindo Persada.

Sardiman. (2011). Interaksi \& Motivasi Belajar Mengajar. Jakarta: PT. Raja Grafindo Persada.

Slameto. (2013). Belajar dan Faktor-faktor yang Mempengaruhinya. Jakarta: Rineka Cipta. 
Sujana, N. (2005). Statistika Pendidikan. Bandung: Rosdakarya.

Syah, Muhibbin. (2010). Psikologi Pendidikan. Bandung: PT. Remaja Rosdakarya.

Syamsudin, A. (2007). Psikologi Kependidikan. Bandung: PT Remaja Rosda

Toto, S., Cecep, A., E, S., \& Udji, A. (1997). Pendidikan Agama Islam. Bandung: Tiga Mutiara.

Usman, U. (1998) ). Menjadi Guru Professional. (Bandung: PT Remaja

Wasty, S. (2012). Psikologi Pendidikan. Jakarta: PT. Rineka Cipta.

Wijaya, C. (1991). Upaya Pembaharuan Dalam Pendidikan Dan Pengajaran. 